https://doi.org/10.23941/ejpe.v12i2.454

\title{
Review of Elizabeth Anderson's Private Government: How Employers Rule Our Lives (and Why We Don't Talk about It). Princeton, NJ: Princeton University Press, 2017, 224 pp.
}

\author{
SAVRIËL DILLINGH \\ Erasmus Medical Center Rotterdam
}

If there are some academics who maintain that philosophers should stay out of politics altogether, Elizabeth Anderson certainly is not one of them. In Private Government, she does not mince words, emphatically calling for a workers' bill of rights and renewed legislative interest in labor unions. To North American sensibilities, this is tantamount to calling for revolution. However, Anderson argues, the situation calls for nothing less as:

Most workplace governments in the United States are dictatorships, in which bosses govern in ways that are largely unaccountable to those who are governed. They don't merely govern workers; they dominate them. This is what I call private government. (xxii)

Backing up this rather bold statement are various dreadful illustrations of abuse of authority. Anderson invokes poultry workers being forced to soil themselves "while their supervisors mock them" (xix), invasive body searches without probable cause, and tyrannical political shepherding both in and out of the work environment. If nothing else, Private Government knows how to tug at the heartstrings; but its emotionally engaging style does not overshadow its argumentative rigor. Ultimately, Anderson offers an insightful account of the philosophical blind spots surrounding corporate authority and governance, how we should approach those blind spots, as well as how they came to be. The book's activist tone is no doubt due to Private Government being a published edition of Anderson's Tanner Lectures on Human Values, delivered at Princeton in 2014. In this volume, those lectures (chapters 1 and 2) are sandwiched between an introduction by political theorist Stephen Macedo, and four original essays by commentators (chapters 3, 4, 5 and 6), which are then followed by Anderson's reactions (chapter 7). That being said, Private Government remains rooted in the material from Anderson's Princeton lectures. 
Chapter 1-the first of Anderson's Tanner Lectures-entitled "When the Market Was 'Left'”, advances a novel historical analysis of the free market. On her account, the market's founding fathers-figures such as Adam Smith and John Locke-were proto-egalitarians of sorts. Far from the arbiter of growth and efficiency it is now, the market was seen primarily as a tool of liberation, a rebellion against "pervasive hierarchies of domination and subordination" (8) brought about by religious doctrine and patriarchalism. Movements driving this idea-for example, the Levellers, the Chartists-sought to remove feudal monopolies and constraints on market exchange not in the name of efficiency, but equality. Interpreting Smith as the primogenial advocate of economic efficiency and a preindustrial growth guru, says Anderson, is based on a critical misreading. Indeed, Smith claimed that commerce would create a populace of independent, self-employed tradesmen and merchants, operating in perfectly competitive markets, but this was in order to achieve "a truly free society of equals" (23). Although efficiency and growth undoubtedly played leading roles in The Wealth of Nations, Smith's aspirations were markedly egalitarian.

Thomas Paine, to this day a symbol of the right-libertarian, should be viewed in a similar light, Anderson argues. Granted, Paine strongly opposed almost any state intrusion, spoke of personal and fiscal responsibility, and touted the benefits of the free market. Yet to radical workers he was a superstar. How is this possible? According to Anderson, on the eve of the Industrial Revolution, Paine was not speaking to a burgeoning industrial proletariat, but to self-employed entrepreneurs-owner and worker in one. His project, then, was to liberate ordinary working people. And, indeed, "when the bulk of the population is self-employed, pleading for relief from state meddling is quite a different proposition than it would be today" (27).

Unfortunately, Smith and Paine both grossly underestimated economies of scale. The Industrial Revolution perverted the market's emancipatory ideal, realizing it only at the cost of darkly sprawling factories, abhorrent labor conditions, and astronomical inequality. In effect, market society produced the opposite of its promoters' egalitarian intent. It granted the owning class-now disjoined from the working class-the power previously wielded by feudal lords. However, Anderson claims, contemporary market defenders continue to champion pre-industrial arguments. These arguments, well-intentioned as they may be, simply no longer apply; the Industrial Revolution made short work of the context in 
which they did. Instead, they led to the rise of a different kind of serfdom, i.e. corporate serfdom. Consequently, modern-day right-libertarians remain fixated on state power alone, whilst being completely blind to corporate power-a type of "political hemiagnosia" (58).

Chapter 2-the second of Anderson's Tanner Lectures-elaborates on the sweeping effects of this mistake in reasoning. Most importantly, she states:

we don't have good ways to talk about the way bosses rule workers' lives. Instead, we talk as if workers aren't ruled by their bosses. We are told that unregulated markets make us free, and that the only threat to our liberties is the state. We are told that in the market, all transactions are voluntary. We are told that, since workers freely enter and exit the labor contract, they are perfectly free under it: bosses have no more authority over workers than customers have over their grocer. (xx)

Thus, the operative side-effect of the Industrial Revolution seems to be that we still think of workers as self-employed entrepreneurs-all of us tradesmen, merchants, and artisans. History simply has not yet given us the language with which we can speak of corporate authority. As an antidote, Anderson posits analyzing the firm as a type of private government (as opposed to public government). Of course, since employer authority is largely arbitrary and unaccountable, more often than not private governments are authoritarian. The book colorfully refers to them as "communist dictatorships in our midst" (37).

Not even Coase's theory of the firm can justify the sheer extent of the power wielded by employers, according to Anderson. Surely, it tells the story of how the somewhat hierarchical firm came to exist-to combat uneconomical transaction costs associated with contracting, bargaining and information gathering-but it does not, for instance, justify how many employers exercise authority over their employees after their shift has already ended. Nor does it explain an employee being fired over a Twitter post. Of course, authoritarian governments rarely offer exit opportunities like firms do, but according to Anderson, this "is like saying that Mussolini was not a dictator, because Italians could emigrate" (55). American at-will workers may be fired for no reason whatsoever, but they may also quit whenever they like. Some right-libertarian writers have construed this as a commensurate type of authority. In leaving, an employee is sort of firing their employer (and hiring another one if they want to meet rent that month). Even if that were true, says Anderson, there is no 
way for them to fire their boss and force her to find new employees. At the end of the day, a worker has much more to lose by quitting (or firing her boss, if you will) than an employer has to lose by firing a worker. Finally, Anderson calls for the acknowledgement of the reality of private governments and offers several starting venues for research into solutions, including the aforementioned bill of workers' rights and new forms of labor unions.

The chapters immediately following are devoted to four essays responding to Anderson's work. Historian Ann Hughes, in "Learning from the Levellers?", posits that Anderson's understandably incomplete account of the Leveller movement may yield some slightly different theoretical results if certain historical omissions are restored. Hughes sets out to inject nuance into several aspects of Anderson's first lecture. Firstly, she characterizes the realities of early modern society and economics; subsequently, she characterizes the form of the early modern market; and finally, she characterizes the status of women in the Leveller movement. Although this nuance makes for a thorough and interesting read, ultimately it does not make a significant contribution to Private Government's central thesis. Following, David Bromwich's essay, "Market Rationalization", fares somewhat better. The literary theorist deftly shows how Anderson's reading of Smith and Paine is perhaps overly selective. Moreover, he decries that Private Government largely omits relevant questions of power and exploitation. Yet, Bromwich fails to adequately develop these interesting observations and so finally settles on the level of merely interesting (though it is at times meandering). Next, political philosopher Niko Kolodny questions if Private Government plays a little too fast and loose with the concept of 'government'. In his essay, "Help Wanted: Subordinates", Kolodny argues that Anderson's analogy is more than a little strained (and rightly so). Yet, his analysis seems largely to have missed that Anderson's intent is not to formulate a philosophically consistent theory of employer authority, but to offer a simple lens-a languagewith which we could identify the problem in the first place. This brings us to the final essay. One would hope economist and staunch libertarian Tyler Cowen's rebuttal, “Work Isn't So Bad after All”, would set off the fireworks. But alas, Cowen meekly (yet accurately) asks us to consider employer abuses in the light of the gains incurred by workers in Anderson's private governments. He claims that these abuses, in the face of much evidence I might add, are few and far between, and that corporate 
authority's benefits therefore far outweigh its costs. Whether this calculus checks out remains to be seen, but Cowen is not wrong to ask Anderson to engage with contemporary market justifications-those to do with efficient allocation of resources-even if we were to grant that the market's origins had a more egalitarian slant. True to form, and much less self-deprecating than I would have liked, Cowen ultimately blames most employer abuses (those caused by worker dependence, at least) on bad government policy.

Anderson's responses are friendly enough. She rarely concedes a point, however, and one may pick up on a sliver of exasperation some pages in. Anderson continuously hammers home her point, repeatedly restates her project, and then finally restates it some more. One can hardly blame her; her critics barely engage with Private Government's (somewhat blunt) argument at all, choosing instead to take small (though accurate) and inconsequential potshots at the book. In doing so, they seem to unrelentingly misinterpret its core thesis. Whether that is because they do not really understand Anderson's project, or because they do not want to, remains unclear. It does, however, cause the commentary chapters to fall entirely flat. Their inclusion adds little: some interesting footnotes, perhaps, but no real depth or argumentative engagement.

It seems clear to me that this is a problem to do with Private Government's target audience. Anderson claims her readers will most likely be "tenured or tenure-track professors" (62), but she has written a book for organizers, activists, and work-floor revolutionaries. To subject Private Government to rigorous academic scrutiny is, in that sense, to miss the point. True, there are some academic high notes. Most notable is Anderson's extraordinary historical analysis that offers the reader a convincing genealogy of right-libertarian argumentation. Commentator Hughes quickly points out that even this genealogy is not historically thorough. But it nonetheless skillfully shows why, philosophically, too many staunch market defenders seem to confuse freedom with servitude.

Ultimately, though, Anderson is unable to escape the paradigms history has created for us. Private Government succeeds marvelously in bringing to light a problem that is invisible to many but will fail to convince those who are not already convinced. Critically, Anderson overstates the similarity between state and firm, and she is not the only political philosopher to do so. In fact, this phenomenon has been extensively written on, most notably by Joseph Heath, Jeffrey Moriarty, and Wayne 
Norman. They argue that "[a] variety of writers reject these [types of] arguments because of what they see as morally relevant differences between states and firms. The most commonly cited difference is voluntariness: both the decision to join and to leave is more voluntary for the firm than for the state" (Heath, Moriarty, and Norman 2010, 437). Of course, because Private Government is primarily in the business of firing opening salvos, it does not engage with these differences in any academically meaningful sense.

Accordingly, Anderson neglects to investigate the justifications that are already implicit in market institutions. And, as Tyler Cowen identifies, these are exactly the justifications her political opponents are concerned with. In her defense, opting not to hold this debate on her opponents' turf allows her to persuade those readers who have not (yet) picked a side to think methodically about freedom and authority within the firm. But this strategy comes at the expense of theoretical rigor. Opening salvos are rarely nuanced, however (I join Anderson here in pretending there has not already been many a philosophical opening salvo aimed at authority in the firm). In sum, Private Government most certainly does not miss its mark.

\section{REFERENCES}

Heath, Joseph, Jeffrey Moriarty, and Wayne Norman. 2010. "Business Ethics and (or as) Political Philosophy.” Business Ethics Quarterly 20 (3): 427-452.

Savriël Dillingh teaches medical ethics at the Erasmus Medical Center in Rotterdam and consults for the World Wide Fund for Nature (WWF). He is interested in the ways in which political philosophy and business ethics overlap-specifically in the convergence of cooperative forms of business, decentralized economies and left-libertarianism.

Contact e-mail: <s.dillingh@erasmusmc.nl> 